\title{
Selling 'hot air': An Analysis of the Perceived Media Influence on Prosperity Gospel Related Gullibility in Zimbabwe
}

\section{Wellington Gadzikwa}

\begin{abstract}
The close to three-decade economic and political crisis in Zimbabwe, or what is commonly known as the 'Zimbabwean Crisis' (Raftopoulos 2009) has brought desperation to many Zimbabweans. In almost every facet of life the church has become a form of refuge. What has baffled many observers is the manner in which the populace has imbibed the Prosperity Gospel and its promises in a land that resembles a desert. The mushrooming of Prosperity Gospel churches in Zimbabwe, in which only the leaders of these churches have prospered materially, while congregants continued to live on faith and hope, demonstrates among other things how gullible our society has become. Through an analysis of selected print media articles on Prosperity Gospel in mainstream newspapers in Zimbabwe and structured key informant interviews, this article argues that the media, through mass manipulation, have to a large extent aided and entrenched religious gullibility in unprecedented ways even among the elite.
\end{abstract}

Keywords: media, agenda setting, social responsibility, magic bullet theory, gullibility, and prosperity gospel.

\section{Pentecostalism as the Foundation of the Gospel of Prosperity}

For a clear understanding of the media influence on gullibility in as far as Prosperity Gospel is concerned, Pentecostalism and the Pentecostal movement emerge as the key components. The gospel of prosperity is promoted by Pentecostal churches, or what is known as Pentecostalism. According to Chinkwo (2017), Pentecostalism has had a dramatic development over the 
past century, greatly transforming Christianity. Pentecostalism has been described as a renewal movement within Christianity, a continuation of a series of revival movement from the earliest days of the church (Kay 2011). As noted by Block-Hoell (1964), the Pentecostal movement is rooted in the holiness movement and can be traced back to an 1886 holiness revival. It is said that groups and individuals scattered around the world experienced baptism by the Holy Spirit, which manifested by speaking in tongues (BlochHoel 1964: 18). As Chinkwo argues, religious groups around the $19^{\text {th }}$ century anticipated the return of Christ and revival meetings were held. Despite controversy of the root of the modern Pentecostal movement, two names stand out in the form of William Joseph Seymour and Charles Parham Fox as part of the roots (Hollenweger 1997).

Although Pentecostalism exhibits more complexities in terms of its definition, this article is informed by the one advanced by Asamoah-Gyadu (2005: 12), who defines Pentecostalism as,

Christian groups which emphasises salvation in Christ as a transformative experience wrought by the Holy Spirit and in which pneumatic phenomenon including speaking in tongues, prophecies, visions, healing and miracles in general perceived as standing in historic continuity with experience of the of the early church as found in the Acts of the Apostles, are sought, accepted, valued and consciously encouraged among members as signifying the presence of God and experience of his spirit.

What is characteristic of Pentecostalism is that it is dynamic and can assume different colours in different parts of the world or what has been described as 'going native' (Kalu 2008: 21). Despite its fluidity and dynamisms, Pentecostalism generally has common characteristics as identified by Droogers (2001: 45-46) which include healing through exorcism, presence of the Holy Spirit experienced through the gift of healing and prophesy, glossolalia or speaking in tongues, conversion experience with a rebirth phenomenon. Pentecostalism also denounces what are called things of the world or one culture and the convert is said to have a new life.

Pentecostals have a dual world, new with God and the believer on the one hand, and the devil on the other side with his agents and followers. Pentecostalism is well established on the African continent and dates back to 


\section{Wellington Gadzikwa}

1920 in Sub- Saharan Africa, with an explosive growth between the 1960s and the 1970s. Estimates are that Christians comprise 50 percent of the African population (Omenyo 2014). A point that must be noted in the discussion of Pentecostalism is that it is linked and is the proponent of the Gospel of Prosperity or Prosperity Gospel, terms which will be used interchangeably in this article.

\section{Prosperity Gospel}

This gospel, like Pentecostalism, which gives birth to it, has a plethora of names which include among others, 'wealth and health', 'faith gospel', or 'name it, claim it gospel'. Prosperity gospel is viewed as a radical departure from the 1970's mature churches that were more concerned with saving souls as opposed to financial achievements. The concern with saving souls has been described as poverty theology that did not encourage the craving for material possessions and viewed it as a curse and something that must be condemned. Thus, people were not supposed to have more attachments to the world (Adogame 2010). In brief, the prosperity theology points to faith for prosperity or the belief that the true faith should be acting on the world, projecting the world into reality and planting a picture of one's desired possession, not forgetting the fact that there is investing before reaping or sowing before harvesting (Kalu 2008).

Although there is disagreement on who began preaching prosperity gospel, E.W. Kenyon and Kenneth Hagin are credited for its invention (Kalu 2008). Kenyon is credited as the leading guide in the journey of Prosperity Gospel mainly through the use of radio where he urged Christians to use their faith to dominate life circumstances and the need to teach principles to allow Christians to rightfully use principles to unlock God's treasury of blessings (Bowler 2013). Prosperity theology has been also popularised by American pastors who were also seen as prophets and visionaries such as A.A. Allen, T.L. Osborn, Oral Roberts, Benny Hinn, Lester Sumrall, Myles Monroe, Creflo Dollar and Joel Osteen. These preachers are described as 'charming, polished if not effusive and slick' (Bowler 2013: 5). Another aspect of the Prosperity Gospel is that the prosperity preachers present themselves as entrepreneurs and stress a victorious or prosperous and healthy living both in the spiritual and physical realm. They also portray God as God of abundance who can provide abundantly, since silver and gold belongs to him. This view 
is contrary to the Holiness movement, which believes that wealth is worldly and carnal; as such, the best designer dress or car or jet are not encouraged.

With its American roots, Prosperity Gospel is now firmly rooted in Africa and the resultant influences. A large segment of African Christian community was influenced by what took place in America and the emphasis on prosperity, and that every Christian must be prosperous. True Christianity warrants wealth and poverty is a sin, or is caused by lack of faith, or inability to understand biblical principles on prosperity.

The basis for these principles is derived from the Bible they use in their preaching such as Deuteronomy 28: 30, Malachi 3: 10, Galatians 3:29, which are interpreted as saying God wants people to be wealthy. The lack of prosperity is attributed to failure to follow Biblical principles (Gifford 1990). When we look at the issue of prosperity gospel, critical aspects that need interrogation is the aspect of poverty and its eradication, which ultimately is the goal of most development actions and programmes by governments and international organisations such as the United Nations and its specialised agencies such as the United Nations Development Programmes (UNDP). An example is the UN Millennium Development Goals 2010-2015 (MDGs) which had the goal of eliminating extreme poverty and its successor Social Development Goals (SDGs) are also directed towards ending poverty. Despite all these concerted efforts to eradicate poverty, success has been elusive and human suffering has increased (Eversole, McNeish \& Cinadamoree 2005). Again, like Pentecostalism and Prosperity Gospel, poverty is also an extremely complex phenomenon in terms of its definition especially its multi-dimensional nature (Crawford \& Hartman 2008; Adeyemi, Ijaiya and Raheem 2009; 2001; Hopper 2012).

Poverty prevents people from living long, healthy and fulfilling lives in terms of enjoying dignity, self-respect and respect from others (Kabuya 2015). The impact of poverty is buttressed by Adeyemi et al. (2009), who argue that poverty manifests a sense of 'lack of material well-being, insecurity, social isolation, psychological distress, lack of freedom of choice and action and lack of long term planning horizon'. From these two positions, poverty then is not just a lack of income and resources, but it entails hunger and malnutrition, limited access to education and basic services, social discrimination and exclusion, lack of participation in decision-making. The United Nations estimates that approximately 836 million people worldwide still live in extreme poverty or on less than \$1 USD per day. On the African 


\section{Wellington Gadzikwa}

continent in the 1990s, almost half (270 million) of the population of 580 million lived in extreme poverty (White et al. 2001) and a least 250 million have no access to safe drinking water, 200 million with no access to medical facilities, and 140 million of the youth are illiterate (Hopper 2012).

Interestingly, statistics from the World Development Report in 1990 indicate that poverty increased dramatically in the 1980s at a time when Pentecostalism with its force for prosperity grew in Africa. The fact remains that the majority of Africans wallow in poverty economically and in terms of teething problems such as unemployment and inequality (Kabuya 2015). All these realities bring to question the perceived power of the Prosperity Gospel in fighting poverty.

\section{Pentecostalism and Poverty}

The Prosperity Gospel is hinged on eradicating poverty by applying Biblical principles. The link between Pentecostalism and poverty needs serious interrogation, especially as there are claims that the gospel can be used to deal with poverty by applying Biblical principles. Early Pentecostalism looked at poverty as a virtue, but today poverty is looked upon as a curse or an evil spirit that needs to be cast out. Poverty is viewed as the primary concern of Jesus Christ; Christians must look at poverty as a form of deprivation. Christians must thus look at the more material aspect of their lives such as shelter, food, and money, including the immaterial ones such as knowledge, skill, healthcare, education and access to opportunities, jobs, and participation in socio-economic life (Kalu 2006). The growth of Pentecostalism on an impoverished continent such as Africa is due to its promises of bringing prosperity to the poor (Togarasei 2011). In his optimistic thesis of the Prosperity Gospel, Togarasei argues that although Pentecostalism is viewed as the gospel of delusion, it has contributed to sustainable development through encouraging entrepreneurship, thereby contributing to poverty alleviation in Africa. According to Togarasei (2011), Pentecostals are encouraged to start their own business, which in turn creates employment; they are expected to pay money to the church every month in the form of seed sowing. It is this money which then enriches the churches and is invested in universities, schools, hospitals. The end result is that employment is created. This is argued to be in line with the Pentecostal doctrine, which does not encourage idleness but encourages them to come up with strategies 
of poverty alleviation. The belief that Pentecostalism can be used to fight poverty has also been criticised for exacerbating the gullibility that manifests in the people in Zimbabwe, as shall be demonstrated in this article, especially on how the media have been a catalyst in sustaining and entrenching this gullibility.

\section{Pentecostalism and Prosperity Gospel in Zimbabwe}

According to Chitando and Biri (2016), the Pentecostal prophetic movement led by young men with gifts of prophesy, healing and deliverance has expanded since 2009. One key attribute of these new and fast-growing religious movements is that they are growing fast and are initiated by young and predominantly male and charismatic leaders (Chitando, Manyonganise \& Mlambo 2013). These movements have altered and changed the face of Christianity in Zimbabwe. Biri and Chitando (2016) maintain that these young prophets and their influence in the public space has heightened debate on prophesy, healing and deliverance, while noting that their main attraction is due to the emphasis on prophecy and prosperity. Like elsewhere in Africa, Pentecostalism grew in the context of socio-political and economic crisis (Zimunya \& Gwara 2013), deliverance and healing being the factor that draws large crowds. The rise of Pentecostal movements led by young and charismatic leaders rose to prominence after the year 2008, which was the lowest point in the Zimbabwean crises punctuated by massive hyperinflation and unemployment. In terms of gullibility, Chitando and Biri (2016) make an interesting point in that these Pentecostal churches have a fair share of controversy, including strange healing miracles, although many Zimbabweans continue to flock to these news churches across class, age and gender. The analysis on whether or not the media can aid in gullibility is supported by that fact that one of the distinct feature of the emerging Pentecostal movements in contemporary Africa has been due to them being techno savvy (Hacket 1998). On the Zimbabwe scene, Biri and Chitando (2016) argue that, for example, the Prophetic Healing and Deliverance (PHD) ministries led by Walter Magaya, have become popular through the use of media technologies, including live coverage of its activities on Zimbabwe Broadcasting Corporation (ZBC TV) and South African television channels such as eNCA. While churches can pay for live coverage, it is the uncritical stance that is associated with sponsored events that diminish the critical watchdog role of 


\section{Wellington Gadzikwa}

the media. Viewers may assume that something on national television is without fault and take it as official, oblivious to the fact that there is sponsorship behind the event. This too can entrench gullibility that would have been created by other factors in society.

Media are key to the spread of messages and global communication. Globalisation has been made possible through the use of the mass media and in terms of the Prosperity Gospel, televangelists who popularised this gospel relied on the media, especially radio and television; hence he term televangelists (Beyer 2006). What is clear is that the spread of Prosperity Gospel world-wide has been helped by the media. The main question that this article tries to answer from a Zimbabwean perspective is whether on the Zimbabwean scene, the mainstream media have aided religious gullibility from a prosperity Gospel perspective where many believe in it, to the extent of parting with the last dollar in their pockets and to believe weird things like miracle money being deposited into their banks accounts on the condition that if they give the little they have to the 'men of God'. This gullibility is much more striking, especially when these people have full knowledge of how the banking system operates and that money does not grow on trees.

In questioning the role of media in aiding gullibility in terms of Prosperity Gospel, the expectation is that the media should test the basic premise of such a gospel. According to Gbote and Kgatla (2014), Prosperity Gospel is 'rooted in faulty interpretation of several Biblical passages' and this gospel portrays wealth and riches as a covenant and fulfilment of the divine promise of God to His people. What is critical in Prosperity Gospel is that God wants believers to get rich or healthy, but He cannot bless them unless they first send money known as 'seed faith' to their spiritual leader or pastor who tells them about their plan. The gullibility of their followers is perceived in their inability to question such teachings, regardless of their levels of education and knowledge of the Bible. It is this gullibility that the former president of Zimbabwe Robert Mugabe questioned in relation to the Prosperity Gospel. A classic and dangerous example of this gullibility is noted by Bishau (2013: 69), who argues,

We have quite some disturbing events especially in Zimbabwe with people believing that tree leaves can be converted into money. An able bodied woman, well in her senses had the audacity to fill a whole trolley with groceries in a respectable supermarket and even 
approach the till operator knowing fully aware that she had no money but tree leaves in her purse but gathered on the basis of 'faith' (or presumption) garnered at a session where the prosperity gospel was preached.

In Zimbabwe, Prosperity Gospel has attracted even those economically up as they seek to further and enhance their wealth. They are also not spared from the gullibility associated with it.

\section{Theoretical Framework}

In this article, the analysis of the media relies on the social responsibility theory and magic bullet to assess whether the media in Zimbabwe have aided religious gullibility or otherwise, and with what effects. Thus the analysis of the role of the media is made in the context that media have certain responsibilities in conducting its business on top of it being a business enterprise. In terms of social responsibility theory, the media should be socially responsible. A socially responsible press should provide,

a full, truthful, comprehensive and intelligent account of the days' events in a context which gives them meaning, serve as a forum for the exchange of comment and criticism, a common carrier of public expression, provide a representative picture of constituent groups in society and present and clarify goals and values of society (McQuail 2010: 170).

From the above quote, it is clear that the media must try to explain a phenomenon in a way that allows readers and audiences to fully comprehend an issue, in this case the Prosperity Gospel as a way to enlighten them on its truthfulness so that they make informed decisions. The media are also expected to critically evaluate and offer a 'full, truthful, comprehensive and intelligent account', which means that it should not in any way aid gullibility but allow deeper and critical understanding of an issue.

The social responsibility theory is a normative theory, an ideal and an expectation for the media but the media should be judged even by what it does and not what it says it will do, as many media organisations offer lofty ideals in their mission statements but do the opposite, mostly in pursuit of 


\section{Wellington Gadzikwa}

profit or due to other ideological influences. The media do have the power to mass spread its messages in ways that have the potential to influence audiences in an identical manner through the magic bullet theory. Magic bullet theorists believe that the media are all powerful and have the ability to shape public opinion or whip it. The belief is that witty messages reach individuals through the mass media and uniformly influence them to act in certain predictable manner. The media messages are seen as magic bullets like a bullet being fired. According to Katz and Lazarsfeld (1955), there is an omnipotent media, on the other hand, sending forth the message, and the atomised masses, on the other hand, waiting to receive it and nothing in between. Receivers of media messages are seen as passive, who accept rather than reject media messages. Despite its criticism of exaggerating the power of the media and being based on flimsy evidence, the magic bullet theory is still relevant even today, as some people still believe in media messages and display a certain level of gullibility and uniformity in their responses to media messages.

The alleged power of the media to influence audiences in terms of Prosperity Gospel is analysed in line with this theory especially as the Prosperity preachers rely on the media to spread their activities and market themselves on various media platforms, especially the print and electronic media in Zimbabwe.

\section{Methodology}

To assess the perceptions on whether the media aided gullibility in terms of Prosperity Gospel, I relied on two qualitative methods in the form of a textual analysis of purposely selected newspaper articles from two writers who in my opinion tried to question the gospel of prosperity, and in-depth interviews with people who follow the media closely and could give a fair assessment on the topic under study. The in-depth interviews asked the one question 'In terms of the Prosperity Gospel, do you think the media in Zimbabwe have aided gullibility, or the unquestioning acceptance of any notion legitimated through an appeal to the Supernatural?'

Four newspaper articles were selected and analysed. More could have been analysed but the themes of the two writers had minor differences and the three that were picked summarised the most critical views of the two writers. The two writers were selected because they offered a critical stance 
that revealed the shortcomings of the media in questioning the deception in terms of the Prosperity Gospel and, more specifically, the two writers sought to expose the fallacy of the Prosperity Gospel. They made specific references to how Prosperity Gospel entrenched gullibility and how the media were complicit in the process. Ten (10) structured interviews were also conducted with people who closely followed the media and were also conversant with Prosperity Gospel. They were asked a similar question as a starting point. The results were analysed and major issues are summarised in the results analysis.

\section{Findings}

\section{Results from Interviews}

There is a general consensus among respondents that the media have aided gullibility in reference to prosperity gospel, although this gullibility is not entirely located in the media itself. It is a combination of the media, political economy and the religious organisation themselves. In terms of the media, respondents were quick to create an easy link between the pervasive use of the media by the prosperity preachers and prophets and gullibility as one asked the question, 'The media has helped to create gullibility. How do you explain a situation where Star FM, Power FM all broadcast the service of PHD Ministry' (Interview 28/07/18).

These sentiments also correspond with conclusions by Chitando and Biri (2016) that PHD ministries managed to establish and entrench itself through the use of live broadcast on ZBC TV and eNCa, respectively. While some respondents believed that the media have its fair share in aiding gullibility, they also pointed to other factors at play, such as pure greediness. As one media analyst noted,

Also coming with this upsurge in religious content from the Pentecostal movements that preach prosperity gospel were shocking incidences of gullibility, people doing the unthinkable in pursuit of prosperity. The case of a Harare man who lost his Bentley to Urbert Engel and the couple that lost houses to Makandiwa as seed for prosperity are just but a tip of the iceberg. The media's involvement in this should be understood from the political economy perspective where media ended up turning to these prosperity preachers as the only reliable source of revenue since the economy was on a down- 
ward spiral and traditional sources of advertising revenue (companies were closing. Because of the faith people have in the media, the prosperity movements gained traction with many people in Zimbabwe, who ended believing that anything was possible with prosperity churches (Interview 25/07/18).

Economic hardships were also blamed for contributing to the rise in gullibility, as people flocked to these churches in search of economic answers on issues such as employment, business fortunes, health, and many others. These hardships are thought to have driven people more to believe in Prosperity Gospel when compared to the media.

Some journalists strongly believe that the media promoted gullibility around Prosperity Gospel when they published stories of high-profile people, complete with pictures of their spiritual deliverance and results. One such example is a government Minister Oppah Muchinguri-Kashiri, who claimed that she got married after attending TB Joshua's church. Her testimony was publicised in the press. Another high-profile figure like former Minister Saviour Kasukuwere was also pictured in Bulawayo seeking divine help from prophet Blessing Chiza when he was facing deep political challenges as there were nationwide demonstrations against in his party. After the meeting with the prophet, his fortunes changed for the better. These were singled out as some of the examples that could aid gullibility among the people into believing in anything that prosperity prophets would say.

A journalist said that at a certain media house where she worked, stories of Prophets Emmanuel Makandiwa of United Family International Church (UFIC) and Walter Magaya of PHD were given prominence and placed on page one of the newspaper. Some stories were extensively written to promote the major programmes of these churches. One such example was Magaya's Night of Turn Around where there were reports that people were being delivered. The journalist believed that the publication of pictures and success stories at churches, especially those of congregants being healed of diseases like cancer led the nation to be gullible (Interview 20/07/18).

Again, the broadcast media were described as worse, especially the national commercial radio stations such as Star FM, which carry adverts of prophets making people believe without thinking or considering whether this was true or not. The overall impression from a journalistic point of view is that the media in Zimbabwe are guilty of causing a national gullibility to the 
Prosperity Gospel and philosophy of quick returns (Interview 20/07/18).

Media-aided gullibility was also perceived to be in the form of the media failing to play its watchdog role and socially responsibilities, but instead played a catalytic role in being an unquestioning conveyer belt in mass manipulation. The media were accused of failing to question the 'miraclemoney' phenomena (where airtime appeared mysteriously in congregant's phones, cash in wallets and deposits into bank accounts), which was purporttedly 'pioneered' by one Prophet Uebert Angel around the year 2012 and 2013. The accusation was that by the time media practitioners reported on the phenomenon, they were joining a discussion that has already been framed on social media platforms and the public. As one media academic noted,

They were (mainstream media) 'scooped' as it were and without sound knowledge of Biblical Theology, media practitioners were reduced to gossip mongers, effectively making them as gullible as other members of the public. It was left to social commentators like Zimdancehall artists Cello Culture and Soul Jah Love (see their track 'Minana' and Winky D (see his track 'Mumba Mababa') to interrogate the phenomena by juxtaposing it against traditional Zimbabwean as well as Christian values. The whole phenomena was also interrogated more robustly by bankers and sceptics. What are the implications on the fiscus? Is this money being deducted from the Central Bank's vaults, etc? Some media practitioners argued and acted like vanavaPapa, loosely translated into 'children of the prophet' with more robust debate taking place in the comments sections of online articles. The more they purportedly 'covered' the story the more they provided public relations for the proponent. It was also alleged that compromised media practitioners had been 'captured' as they were alleged to be on the payroll of prosperity gospel (the purveyors of miracle money) proponents (Interview 19/07/18).

The above sentiments point to an equally gullible media which failed to play their role in society and thus aided gullibility. Gullibility associated with Prosperity Gospel was perceived to thrive in an environment where the material conditions of the population are at its worst. The rise of the Prosperity Gospel was described as being diametrically linked to the fall of the 


\section{Wellington Gadzikwa}

economy and that its demise will directly be linked to the rise of the economy. In the scheme of things, the media were accused as being a willing partner in the spread of this gospel, because of the media's intention to tap into the revenues being generated through advertising by the prosperity preachers. Thus, the media found themselves in fierce competition to showcase prosperity pastors in order to generate as much revenue as possible through advertising.

A tabloid newspaper in Harare, the H-Metro, was cited as one example of a newspaper that has continuously given prosperity pastors columns in an attempt to get advertising money. The other accusations are that the newspapers also follow these pastors, because sometimes they make some ludicrous claims, which happen to make news, such as making miracle babies, miracle money and organ enlargement, among others (Interview 19/07/18). Instead of questioning these claims, the media actually popularised them as juicy stories in order to increase newspaper sales, thereby contributing to the trivialisation and uncritical approach to such issues.

The relationship between the media and these prosperity preachers becomes so intricate and resultantly aids and entrenches gullibility. By giving space to these prophets, the media are believed to lend them some credibility, which acts as magic bullets to promote gullibility as some spaces, especially in The Sunday Mail as one respondent noted that,

In The Sunday Mail we have a particular lady columnist who has become a de facto mouthpiece of the prosperity prophets instead of questioning them or simply being objective. On one station, Makandiwa actually preaches every 5:30 am to 6am spewing gospel of prosperity philosophy (Interview 19/07/18).

As a result of the seemingly evident successes through the use of the media, preachers have also invested in modern media technologies, establishing television stations, recording and posting content on social media because they have realised that exposure to any kind of media enhances their reputation and credibility among the citizens.

While there is consensus that the media in Zimbabwe have been complicit in promoting the unquestioning acceptance of any notion legitimated through an appeal to the supernatural, there are several reasons which predispose Zimbabweans to be susceptible to this gullibility. As one respon- 
dent argued, Zimbabweans have for the past three decades been so proud to call themselves a Christian nation/society, which on its own forms a baseline for unquestioned belief in supernatural powers. Thus the society does not question supernatural powers and accept supernatural powers at face value. They only mock outcomes such as those of Rotina Mavhunga, a traditional witchdoctor who made sensational claims that diesel could flow from rocks in Chinhoyi. Then President Robert Mugabe sent a cabinet taskforce that confirmed the story's claims, rewarding Mavhunga with huge sums of money, although the story turned out to be fake. In this case, the Zimbabwean society can be characterized more as a spiritual society that assumes traits of the dominant or accepted religion at any given time. During the war it was midzimu (spirit mediums) and after the war, with the adoption of modernity, it became Christianity.

In such a scenario, as one media analyst observed, individuals brought up in such a society unquestionably assume the same beliefs in their professional work, which includes journalists, editors and media owners. Both the practice and media ownership are thus driven by people with allegiance to some form of religion and for this reason, Prosperity Gospel found a fertile ground to grow, albeit largely unquestionably. One such aspect is a case where prosperity gospel prophets were in the habit of giving prophesies on the yearly outlook. They were given acres of space in newspapers, even when some of the prophecies were out of this world, including the raining of gold and diamond from the skies, the miracle money from Automated Teller Machines (ATMs), miracle babies and many others. In all this, the media and journalists did not ask what happened to these miracles, but merely acted as conveyer belts.

Some of the reasons for the gullibility and fear of questioning have been summed up by one media analyst who believes that it is fear of the supernatural that prevents people form questioning some of these Prosperity Gospel-related gullibility because,

Prosperity gospel as a concept is built on the belief that worship leads to emancipation. If you believe, you will be saved. During Zimbabwe's liberation war, it was the same. If you worship Nehanda, you will conquer. It is a belief that diminishes or fails to acknowledge human effort from outcomes and attributes all the good outcomes to superpowers and all the bad things to the devil. It takes 


\section{Wellington Gadzikwa}

away responsibility and allocate it somewhere else which allays human fears for blame or guilt. If poor, it means you are not blessed and you need prayers. If you are rich, it means you have been blessed and therefore you need to give more to the church of God. And those who do not comply to this mode of thinking are seen as heretical who shall suffer in the hands of God in heaven. Because we fear hell and suffering, no one wants to take the risk of questioning our churches and for that reason, the prosperity gospel has grown and continues to grow to the detriment of our economy (Interview 20/07/18).

The fears expressed in the quotation above resonates with the backlash that writers such as Wafawarova and Guvamombe (see next section) claimed to face when they dared to question the Prosperity Gospel. It also shows the violence that is associated with attempts at criticizing this gospel and how it capitalizes on the beliefs in not questioning the supernatural and the helplessness that individuals feel about the power of the supernatural. More specifically, the fear of hell and suffering enhance the gullibility in the form of failure to question. Even those materially rich end up giving because of fear, while the poor give, thinking that they will get more. Journalists as members of society may as well fear to go against strong societal conventions and fears, especially when the owners of the media houses are cashing in on this gospel through advertising revenue. This greatly diminishes the power of the media to play its social responsibility role as watchdogs especially in a comatose and moribund economy like Zimbabwe. In the end, the media by default or design, end up aiding religious gullibility especially in terms of Prosperity Gospel.

In the next section, I examine the perceptions the works of two media critics who offer a critical stance to Prosperity Gospel by exposing its ills and showing that to some extent the media have not unwittingly aided gullibility and have acted in a socially responsible way.

\section{Textual Analysis of Newspaper Articles}

The Prosperity Gospel has not been without critics. Among the most consisttent critics of this gospel in the print media include two columnists from the Zimpapers group (State-controlled media group and the largest in the 
country), Reason Wafawarova and Isdore Guvamombe, who also revealed that they had been vilified for expressing their views that sought to expose the deceptive nature of this gospel. What their writings reveal is the fact that the media have not unwittingly aided gullibility, but have tried to expose it, in a sense acting responsibly as watchdogs in society.

\section{Gospreneurship, Christianity and Churchianity}

In an article entitled 'Cow dung naturally attracts flies' (Guvamombe 2015a). Guvambombe likens Prosperity Gospel to cow dung and refers to it as fetid, something abnormal, arguing that 'in the abnormal, the fetid is more attractive than delicious'. In his analysis, Guvamombe believes that in Zimbabwe, there exists what he describes as Churchianity and Christianity, arguing that most people in Zimbabwe practise Churchianity instead of Christianity. For him Christianity is where,

Jesus Christ is the life, the principal, the harbinger of life and love, the embodiment of righteousness: the visionary and cleanser of all evil. Jesus Christ is the moralist, the epicentre of everything,

while in Churchianity,

The church is the cynosure, the pastor, prophet and prophetess is the supreme epicentre - the all-important. The pastor, prophet and prophetess - usually smartly dressed and living larger-than-life but has another earthly 'godfather' in Ghana or Nigeria, who ironically is not Jesus Christ or God. It is from the earthly godfather that the prophet, pastor or prophetess derive their powers. Every year, they religiously go back to their godfathers for more powers. They pay for the powers. Is this Christianity? No, never!

Guvamombe makes interesting points in terms of gullibility in that Churchianity is cashing on what he calls the 'poor, troubled and gullible'. What he is critical of is this Churchianity in which the whole setup is a family business and the prophet and the family become 'gospreneurs'. They abuse Christ by using His name as a smokescreen to hide the systematic fleecing of the 'poor, troubled and gullible'. The sermons by these preachers whom he 


\section{Wellington Gadzikwa}

describes as 'gospreneurs' is described as 'the sort of hullabaloo that makes the poor part with the last cent as they seek deliverance'. From the above quote, the picture that emerges is that instead of this gospel empowering, it is actually impoverishing and cashing in on the poor whose prospects for deliverance drive them more into dire situations.

Another critical aspect that characterises the prosperity preachers in Zimbabwe, as Guvamombe notes, is the large entourage of security personnel that the prophets and prophetesses have and the tricking of congregants that anointing oil and wristbands would protect them when the leaders who give these do not put them on and seek protection from bodyguards. Guvamombe makes interesting comparisons between the prophets and prophetesses and spirit mediums that do not need protection because they are not business people. For him, the prophets who need protection show that they are in business disguised as Christianity or simply Churchianity. In the same vein, he alludes to the fact that spirit mediums are not 'gospreneurs', as their protection comes from the spiritual realm. He gives examples of spirit mediums such as Karimatundu, Dumburechuma, Dandajena, Chingowo, Mutota and Kangamiti, who do not need that kind of physical security.

Another factor that Guvamombe points out is the violence associated with prosperity gospel in Zimbabwe, which has also aided gullibility. He points out that genuinely upright people have ideas and reservations about Churchianity, but are afraid of speaking out, due to retribution and fear that one should not attack the anointed ones. Thus, Churchianity ends up attracting more people than Christianity because the spiritual realm is now filled with fly-by-night prophets who are making money and building big business empires and who should be taxed by the authorities in Zimbabwe. Guvamombe's analysis, which is mainly centred on the Pentecostal churches such as UFIC, PHD and Spirit Embassy directly challenges Togarasei's (2011) assertions that these movements have had an impact on alleviating poverty as he argues,

Gone are the days when our people and Government should not be hoodwinked into thinking the Pentecostal churches are charitable organisations. Unlike the conventional churches that built schools and hospitals that have saved millions of people, these ones specialise in false prophecy and lure people with a hodgepodge of miracles. Most of the miracles like refuelling cars, miracle money, 
miracle babies and many nonsensical things are used as baits to gullible people who end up paying through their nose.

Again, Guvamombe is critical of the miracles performed by these prophets as 'silly miracles that sire babies in three days when Jesus Christ himself was born on normal gestation'. This kind of analysis is critical in dealing with gullibility of those who believe in such miracles, and in a way the media are questioning these miracles and exposing their fallacies.

Again, another aspect that could have contributed to the gullibility associated with Prosperity Gospel is that those who question it are chided. Guvamombe claims that he has lost friends for being critical through his writings on Prosperity Gospel and he was called names like (Mhondoro) or spirit medium, meaning that he was fighting on the dark side or evil in the dichotomy of the good versus bad that characterises Pentecostalism.

Guvamombe claims that he was persecuted and stopped from writing his column by powerful politicians when he challenged prophets Emmanuel Makandiwa and Eubert Angel Madzanire on some of their healing claims and differentiated between what he termed 'religion and religiosity or the art and the belief: the belief and the execution of the belief'. His challenge was that,

gospreneurship was an art of making money versus seeking God and he questioned if God anointed between the sheets or whether prophetic powers were sexually transmitted in that a prophet's wife becomes a prophetess (Guvamombe 2015b).

These are some of the aspects that most people do not question and this represents some kind of gullibility. For Guvamombe, these Pentecostal churches must be taxed, because they fleece the poor and makes millions out of what he calls 'troubled' souls. These prophets are described as 'business people whose business model is to milk the poor, the troubled and the gullible'. In a sense, Guvamombe seems to locate this gullibility somewhere else as something that exists out there and he does not specifically accuse the media of aiding this gullibility. For him, the fear in criticising the so-called men of God creates a perception which becomes real. This fear of the unknown, he argues, 'transforms gullibility and the very little that one has can easily be given away to the few who are enterprising and claiming to have access to God' (Guvamombe 2015b). It seems that it is this fear that 


\section{Wellington Gadzikwa}

prophets use to hoodwink people that they are investing in God. Again Guvamombe does not dispute their miracles, because he believes that both evil and holy people can perform these. His bone of contention is that in Zimbabwe, Pentecostal prophets do not want the authenticity of their miracles to be challenged and they use their supposedly express access to God to induce fear in the minds of the 'poor and gullible to part with the little money they have'. For him this gospel is impoverishing and deceptive. In one of his critical articles, Guvamombe (2014) argues that the prosperity prophets capitalise on antics such as enlargement of tiny manhood, raising the dead, selling anointed water and bricks, anointed condoms, pens and soccer results prediction. He claims that people have become gullible to these antics and are like sheep without a clue to survive - 'they sheepishly flock there' - and that his writings are a way to challenge this gullibility. To expose some of the false prophets, Guvamombe gives an example of a Bulawayo-based prophet Blessing Chiza, who mis-predicted a win for the Zimbabwe senior men's soccer team and later admitted that he had not seen well and that his prophecies were not 100 percent accurate, because he was not God. For Guvamombe then it seems many people are making money out of religion by hoodwinking Zimbabweans into believing in even some of the silliest of all things. His major contention is that prosperity gospel has not enriched those who sow, as they remain poor and are getting poorer socially and financially, and that the government must intervene to stop this phenomenon, which he describes as some form of cultism.

\section{Prosperity Gospel as a Curse and Media Culpability}

Another critic of Prosperity Gospel, Reason Wafawarova (2015), describes this gospel as one that is cursed. For him the Prosperity Gospel is a curse which is threatening what he calls 'the nobility and integrity of the Christian faith today ... fuels greed, and it focuses on getting as opposed to giving. It is a selfish materialistic faith with a thin veneer of Christianity' Wafawarova exposes the pitfalls of the Prosperity Gospel in that instead of being a blessing, the gospel is a curse, because it encourages shortcuts where people are promised instant results and overnight success, including securing husbands for the desperate unmarried and ageing ladies. And when these promises fail to materialise as is the case most of the time, the follower is simply blamed for not giving enough money in offerings, or for lacking in 
faith. For Wafawarova then the Prosperity Gospel has actually kept people in poverty by promoting false hope to the masses, pacifying them not to question those in power for laziness and corruption. Like Guvamombe, Wafawarova believes that the claims that Prosperity Gospel can help to alleviate poverty is faulty, as he argues that,

in the past 25 years Sub Saharan Africa is the only place on earth where poverty has been on the increase, and clearly the much hailed Prosperity Gospel is not bringing prosperity to the continent.

In terms of the role of the media in aiding gullibility, Wafawarova (2014) believes that the media are complicit and guilty of aiding gullibility as he argues that the media have failed to question it as one of its expected roles in society, arguing that 'it is surprising that well trained editors in our media fraternity allowed the nonsense to pass for news'. In so doing he accuses the media for an uncritical stance in merely reporting news about the prosperity gospel and miracles without questioning their authenticity, which can point to a marriage of some sort. Wafawarova (2015) also echoes the violence that those who dare to criticise the Prosperity Gospel face, as alluded to by Guvamombe in that: '.. and when sober minded people questioned the logic of honouring this gospel ... they are met with the fury of expectant follower'. What these two columnists have managed to do is to show that the gullibility associated with Prosperity Gospel has been questioned and exposed in the media and the media have in this way been a leading light to fight gullibility insofar as Prosperity Gospel is concerned. There are thus very few writers who have the courage to openly challenge this gospel and its practices, although they claim to have drawn the ire of those who follow the gospel.

\section{Conclusion}

While there can be disagreements on whether Prosperity Gospel is good or bad, the consensus is that to a certain extent the media have aided gullibility instead of being the society's watchdog against false and inaccurate discernment of prosperity according to Bible. The media's role in aiding human gullibility in terms of the prosperity gospel cannot be underestimated.

It seems the prosperity preachers understood the power of the media to mass spread their messages and they invested heavily in such programmes 


\section{Wellington Gadzikwa}

to reap huge rewards, while the media houses also cashed in, especially in an economy where the industry is almost in a state of being comatose. Also, the choice of radio and television meant that the message would reach most people, and because radio does not require the audience to be literate but only to understand the language. Radio is a cheap and accessible medium with the potential to spread the messages faster. Television has the advantage of liveliness, and through motion pictures people can give testimonies, and the 'healing' can be performed for all to see and be convinced.

The use of media such as television has enhanced gullibility on Prosperity Gospel, since their content has been presented in an unquestioned stance as either advertisements or sponsored programmes. People who are overwhelmed by the messages in both electronic media tend to believe the wildest of those messages and throng these churches, expecting instant financial miracle. In this way the media messages function as magic bullets that produce an almost uniform response, as people assume that if something has been published by the media it will necessarily be authentic.

To play their social responsibility role, the media should be critical and abandon the linear, inert approaches that only end with narratives that perpetuate gullibility and offer no alternative narratives. It is also disheartening to note that the media have aided gullibility due to its homogeneous, monotonous tone, which ends with mere reportage, glorification and defence of trends, rather than offering empowering and critical views that enlighten citizens.

The media have thus aided gullibility in the Zimbabwean society, a society that has nothing to look forward to. Drained of material resources, afflicted by joblessness, bleak economic prospects can only hope in the possibility of a miracle. Desperate to escape their poverty and a need for encouragement, people were also quick to accept Prosperity Gospel and the media have come in handy as a mobilisation tool.

\section{References}

Adeyemi, S.L., G.T. Ijaiya \& U.A. Raheem et al. 2009. Determinants of Poverty in Sub-Saharan Africa. African Research Review: An International Multi-Disciplinary Journal, Ethiopia 3,2, January: 162-177. https://doi.org/10.4314/afrrev.v3i2.43617

Adogame, A. 2010. How God became a Nigerian: Religious Impulse and the 
Unfolding of a Nation. Journal of Contemporary African Studies 28,4: 479-98.

https://doi.org/10.1080/02589001.2010.512742

Asamoah-Gyadu, J.K. 2005. African Charismatics: Current Developments within Independent Pentecostalism in Ghana. Leiden: Brill.

https://doi.org/10.1163/9789047406303

Beyer, P. 2006. Religion in Global Society. London: Routledge.

Bloch-Hoell, N. 1964. The Pentecostal Movement: Its Origin, Development, and Distinctive Character. Oslo: Universitetsforlaget.

Bishau, D. 2013. The Prosperity Gospel: An Investigation into its Pros and

Cons with Examples Drawn from Zimbabwe. International Open and Distance Learning Journal 1,1, June: 65 -75.

Bowler, K. 2013. Blessed: A History of the American Prosperity Gospel. New York: Oxford University Press.

https://doi.org/10.1093/acprof:oso/9780199827695.001.0001

Chinkwo, R.N. 2017. Poverty, Prosperity and Faith: An Analysis of the Prosperity Gospel in the neo-Pentecostal Church Winners Chapel International in Bamenda, Cameroon. Unpublished M.A. Thesis, MF Norwegian School of Theology.

Chitando, E. \& K. Biri 2016. Alter Magaya's Prophetic Healing and Deliverance (PHD) Ministries and Pentecostalism in Zimbabwe: A Preliminary Study with Particular Reference to Ecumenism. Studia Historiae Ecclesiasticae 42,2: 72-85.

Chitando, E., M. Manyonganise \& O.B. Mlambo 2013. Young, Male and Polished Masculinities: Generational Shifts and Pentecostal Prophets in Zimbabwe. In Chitando E., M.R. Gunda \& J. Kügler (eds.): Prophets, Profits and the Bible in Zimbabwe. Bamberg: University of Bamberg Press.

Crawford, H. \& C. Gordon (eds.). 2008. Decentralization in Africa: A Pathway out of Poverty and Conflict? Amsterdam: University Press.

https://doi.org/10.5117/9789053569344

Droogers, A. 2001. Globalization and Pentecostal Success. In Corten, A. \& R.M. Fratani (eds.): Between Babel and Pentecost: Transnational Pentecostalism in Africa and Latin America. London: Hurst \& Company.

Eversole, R., J.A. McNeish \& A. Cimadamore 2005. Indigenous Peoples and Poverty - An International Perspective. London: Zed Books.

https://doi.org/10.5040/9781350220751 
Gbote, E.Z.M. \& S.T. Kgatla 2014. Prosperity Gospel: A Missiological Assessment. HTS Teologiese Studies/ Theological Studies 70,1: Art. \#2105, 10 pages. Available at: http://dx.doi.org/10.4102/hts.v70i1.2105 (Accessed on 19/08/2018). https://doi.org/10.4102/hts.v70i1.2105

Gifford, P. 1990. Prosperity: A New and Foreign Element in African Christianity. Religion 20,4: 373-388.

https://doi.org/10.1016/0048-721X(90)90119-Q

Guvamombe, I. 2014. Welcome to Zimbabwe's Gospreneurship Buffet. The Herald 30 January.

Guvamombe, I. 2015a. Cow Dung Naturally Attracts Flies. The Herald 09 July.

Guvamombe, I. 2015b. Why Churches must Pay Tax. The Herald 03 July.

Hackett, R. 1998. Charismatic/ Pentecostal Appropriation of Media Technologies in Nigeria and Ghana. Journal of Religion in Africa 28,3: 258-277.

https://doi.org/10.1163/157006698X00026

Hollenweger, W.J. 1997. Pentecostalism: Origins and Developments Worldwide. USA: Hendrickson.

Hopper, P. 2012. Understanding Development. Cambridge: Polity Press.

Kabuya, F.L. 2015. Fundamental Causes of Poverty in Sub-Saharan Africa.

IOSR Journal of Humanities and Social Science (IOSR-JHSS) 20,6:

Ver. V (Jun.): 78-81.

Kalu, O. 2006. Power, Poverty and Prayer: The Challenges of Poverty and Pluralism in African Christianity: 1960-1996. N.J: Africa World Press.

Kalu, O. 2008. African Pentecostalism: An Introduction. New York: Oxford University Press.

https://doi.org/10.1093/acprof:oso/9780195340006.001.0001

Katz, E., \& P.F. Lazarsfeld 1955. Personal Influence: The Part Played by People in the Flow of Mass Communication. Glencoe, IL: Free Press.

Kay, K.W. 2011. Pentecostalism: A Very Short Introduction. New York: Oxford.

https://doi.org/10.1093/actrade/9780199575152.001.0001

McQuail, D. 2010. Mass Communication Theory. London: Sage.

Omenyo, C.N. 2014. African Pentecostalism. In Robeck, C.M. (Jnr) \& A.

Young (eds.): The Cambridge Companion to Pentecostalism. New York:

Cambridge University Press.

https://doi.org/10.1017/CCO9780511910111.011 
Raftopoulos, B. 2009. The Crisis in Zimbabwe 1998-2008. In Raftopoulos, B. \& A. Mlambo. (eds.): Becoming Zimbabwe: A History from the Colonial Period to 2008. Harare: Weaver Press.

https://doi.org/10.2307/j.ctvk3gmpr.15

Togarasei, L. 2011. The Pentecostal Gospel of Prosperity in African Contexts of Poverty: An Appraisal. Exchange 40,4: 336-360. https://doi.org/10.1163/157254311X600744

Wafawarova, R. 2015. The Curse of the Prosperity Gospel. The Herald 12 February.

White, H., T. Killick, S. Kayizzi-Mugerwa \& M.-A. Savane 2001. African Poverty at the Millennium: Causes, Complexities and Challenges. Washington DC: World Bank. https://doi.org/10.1596/0-8213-4867-1

Zimunya, C.T. \& J. Gwara 2013. Pentecostalism, Prophets and the Distressing Milieu. In Chitando E., M.R. Gunda \& J. Kügler (eds.): Prophets, Profits and the Bible in Zimbabwe. Bamberg: University of Bamberg Press.

\section{Interviews}

28/07/2018 (with a media and political analyst)

25/07/2018 (with a media analyst in Harare)

20/07/2018 (with a journalist in Harare)

19/07/20/18 (with a media lecturer/researcher in Harare)

$20 / 07 / 2018$ (with a media critic in Bulawayo)

Dr. Wellington Gadzikwa Journalism and Media Studies

University of Zimbabwe wmgadzikwa@yahoo.com wmgadzikwa@gmail.com 